\title{
Diachronism in the late Neoproterozoic-Cambrian arc-rift transition of North Gondwana: A comparison of Morocco and the Iberian Ossa-Morena Zone
}

\author{
J. Javier Álvaro ${ }^{\mathrm{a}, *}$, Félix Bellido ${ }^{\mathrm{b}}$, Dominique Gasquet ${ }^{\mathrm{c}}$, M. Francisco Pereira ${ }^{\mathrm{d}}$, Cecilio Quesada ${ }^{\mathrm{b}}$, \\ Teresa Sánchez-García ${ }^{\mathrm{b}}$ \\ ${ }^{a}$ Centro de Astrobiología (CSIC/INTA), Ctra. de Torrejón a Ajalvir km 4, 28850 Torrejón de Ardoz, Spain \\ ${ }^{\mathrm{b}}$ IGME, Ríos Rosas 23, 28003 Madrid, Spain \\ ' EDYTEM, UMR 5204 du CNRS, Université de Savoie, Campus Scientifique, 73376 Le Bourget du Lac, France \\ ${ }^{\mathrm{d}}$ Departamento de Geociências, ECT, Universidade de Évora, IDL, Apt. 94, 7001-554 Évora, Portugal
}

\section{A R T I C L E I N F O}

Article history:

Received 26 November 2013

Received in revised form 20 March 2014

Accepted 23 March 2014

Available online 4 April 2014

\section{Keywords:}

Cadomian and Pan-African belts

Anti-Atlas

Volcanic geochemistry

Ediacaran-Cambrian paleogeography

\begin{abstract}
A B S T R A C T
In the northwestern border of the West African craton (North Gondwana), a transition from late Neoproterozoic subduction/collision to Cambrian rift processes was recorded in the Anti-Atlas (Morocco) and in the Ossa-Morena Zone (Iberia). Cambrian rifting affected both Pan-African and Cadomian basements in a stepwise and diachronous way. Subsequently, both areas evolved into a syn-rift margin episodically punctuated by uplift and tilting that precluded Furongian sedimentation. A comparison of sedimentary, volcanic and geodynamic evolution is made in the late Neoproterozoic (Pan-African and Cadomian) belts and Cambrian rifts trying to solve the apparent diachronous (SW-NE-trending) propagation of an early Palaeozoic rifting regime that finally led to the opening of the Rheic Ocean.
\end{abstract}

(c) 2014 Elsevier Ltd. All rights reserved.

\section{Introduction}

The geodynamic evolution of southern Europe (North Gondwana) during Ediacaran-Cambrian times is a subject that has received much attention in the last decade (Sánchez-García et al., 2003, 2008a; Linnemann et al., 2004, 2008; Pereira et al., 2006, 2008, 2011, 2012a; Nance et al., 2008; Abati et al., 2010; Díez-Fernández et al., 2010; Drost et al., 2011; Avigad et al., 2012; Meinhold et al., 2012). As the Ediacaran-Cambrian rocks are spread out over different regions of North Africa and Europe, it is essential to develop stratigraphic correlation studies to improve the knowledge of the whole evolution of North Gondwana.

During the late Neoproterozoic, North Gondwana included distinct tectonically active regions (Kröner and Stern, 2005): a more peripheral region, facing the ocean (Cadomian belt), and inner regions fringing the cratons (Trans-Saharan belt and East African orogen). In North Africa, the Trans-Saharan belt would have been

\footnotetext{
* Corresponding author.

E-mail addresses: alvarobji@cab.inta-csic.es (J.J. Álvaro),ffbbmm50@gmail.com (F. Bellido), dominique.gasquet@univ-savoie.fr (D. Gasquet), mpereira@uevora.pt (M.F. Pereira), quesada.cecilio@gmail.com (C. Quesada), t.sanchez@igme.es (T. Sánchez-García).
}

an important mountain belt (Transgondwanan Supermountain; Squire et al., 2006) that resulted from the collision of the West African craton with the Saharan Metacraton evolving the Anti-Atlas (Pan-African belt; Kröner and Stern, 2005). The TransSaharan belt consists of a pre-Neoproterozoic basement and Neoproterozoic ophiolites tectonically reworked during the Cryogenian and Ediacaran (Liégeois et al., 2003; Kröner and Stern, 2005). In Morocco, the Anti-Atlas has a stratigraphy characterized by a Palaeoproterozoic basement representative of the northern domains of the West African craton (WAC) (c. 2.2-2 Ga; Reguibat shield; Thomas et al., 2002), subsequently covered by Neoproterozoic volcanosedimentary strata (Thomas et al., 2004; Gasquet et al., 2008; Abati et al., 2010) (Fig. 1). Their involved Cadomian and Pan-African zircon-forming events are sometimes difficult to distinguish because they overlap in time and locally in space (Murphy and Nance, 1991; Nance and Murphy, 1994).

In Europe, the Cadomian belt (Iberia, Cadomia and Bohemia) resulted from the amalgamation process of magmatic arcs and synorogenic basins (peri-Gondwanan terranes; Murphy and Nance, 1991; Nance and Murphy, 1994; Linnemann et al., 2004, 2008; Nance et al., 2008). The Cadomian belt includes a pre-Neoproterozoic basement (Icartian gneiss, 2.1 Ga; Samson and D'Lemos, 1999; Inglis et al., 2004), Cryogenian magmatism (c. 755-745 Ma; orthogneisses from the Penthièvre Complex; Nagy et al., 2002) 